\title{
Calcium Uptake and Binding by Membrane Fractions of Human Placenta: ATP-dependent Calcium Accumulation
}

\author{
JEFFREY A. WHITSETT ${ }^{(30)}$ AND REGINALD C. TSANG \\ Newborn Division Department of Pediatrics, Department of Obstetrics and Gynecology, University of Cincinnati, \\ Children's Hospital Research Foundation, Crosley Memorial Nurserv, Cincinnati, Ohio. USA
}

\section{Summary}

An ATP-dependent calcium $\left(\mathrm{Ca}^{2+}\right)$ sequestration activity was demonstrated in membrane vesicles prepared from the human term placenta. Microsomal and brush border membrane fractions accumulated $\mathrm{Ca}^{2+}$ within a vesicular space by a saturable process requiring $\mathrm{Mg}^{2+}$ and ATP. The "uptake" activity was enriched sixfold in a microsomal membrane fraction and was only 1.5-fold enriched in purified brush border membranes compared to the activity present in the filtered homogenate. Mitochondrial inhibitors such as azide and oligomycin did not inhibit $\mathrm{Ca}^{2+}$ uptake in these preparations. The process was temperature dependent and displayed Michaelis-Menten-like kinetics with respect to free $\mathrm{Ca}^{2+}$ concentrations. At $30^{\circ} \mathrm{C}$, the $V_{\max }$ was $1.05 \mathrm{nmole} / \mathrm{mg} / \mathrm{min} ; K_{m}$ $=74 \mathrm{nM}$ for free $\mathrm{Ca}^{2+}$ in the microsomal fraction. Oxalate and phosphate enhanced uptake in both fractions. $\mathrm{Ca}^{2+}$ uptake activity was not associated with $\mathrm{Ca}^{2+}$-stimulated ATPase, alkaline phosphatase, or other brush border markers during cell fractionation. The characteristics of the $\mathrm{Ca}^{2+}$ uptake process contrasted sharply with those of $\mathrm{Ca}^{2+}$-stimulated ATPase, and a $\mathrm{Ca}^{2+}$-stimulated, $\mathrm{Mg}^{2+}$-dependent ATPase activity could not be identified in these membrane vesicle preparations.

\section{Speculation}

The ATP-dependent $\mathrm{Ca}^{2+}$ uptake activity and $\mathrm{Ca}^{2+}$ binding by placental vesicles are likely to be involved in the regulation of intracellular $\mathrm{Ca}^{2+}$ within the placenta and in the transcellular transport of $\mathrm{Ca}^{2+}$ to the fetus while serving to maintain low intracellular $\mathrm{Ca}^{2+}$ concentrations within the syncytium.

Calcium $\left(\mathrm{Ca}^{2+}\right)$ is transported transcellularly across the placenta from mother to fetus against a concentration gradient (5). The mechanisms involved in such asymmetrical transport have not been clarified. However, it is likely that both intracellular and transcellular $\mathrm{Ca}^{2+}$ are highly regulated by processes which sequester or bind intracellular free $\mathrm{Ca}^{2+}$. Such $\mathrm{Ca}^{2+}$ "pump" activities might protect the syncytium from high intracellular $\mathrm{Ca}^{2+}$ concentrations and play a role in the transport of large quantities of $\mathrm{Ca}^{2+}$ to the fetus. Both $\mathrm{Ca}^{2+}$ binding and ATP-dependent $\mathrm{Ca}^{2+}$ sequestration activities have been described in numerous cell types $(10$, $12,14,15,19,24$ ) and in various subcellular components including plasma membranes (19), mitochondria (2), microsomal membranes $(14,15)$, and sarcoplasmic reticulum (12). In several tissues $\mathrm{Ca}^{2+}$ uptake activity is coupled to $\mathrm{Ca}^{2+}$-stimulated ATPase activity which serves to transport $\mathrm{Ca}^{2+}$ at the expense of ATP hydrolysis $(12,19)$. These relationships, however, have not been demonstrated in the human placenta. Thus, although $\mathrm{Ca}^{2+}$-ATPase activity has been demonstrated in human $(13,27)$ and guinea pig placenta (21), it remains unclear whether this enzyme is associated with placental $\mathrm{Ca}^{2+}$ transport or uptake in placental membranes.

"Brush border membranes" of the syncytium (which are ex- posed directly to maternal blood in the intervillous space) have been recently characterized. These membranes are 10- to 15-fold enriched in $\mathrm{Ca}^{2+}$-ATPase and insulin receptors (27) and also contain a sodium gradient-dependent amino acid transport system (18) but do not contain adenylate cyclase activity (28). Because the first step in the movement of nutrients to the fetus occurs through the brush border membrane, it is likely that it might also have components which might interact with $\mathrm{Ca}^{2+} . \mathrm{Ca}^{2+}$ and other cations have also been observed within vesicular structures $(4,16)$ within the cytosol of the human syncytium. These intracellular membranes or vesicles, as well as the plasma membranes associated with the trophoblastic basement membrane (facing the fetal circulation) might also play a role in the regulation of placental $\mathrm{Ca}^{2+}$. Recently, a placental "microsomal" preparation which is distinct from brush border preparations has been described (26, 28 ). This preparation, which is presumed to be related to plasma membrane near the fetal circulation, is enriched in adenylate cyclase, $\mathrm{Na}^{+}, \mathrm{K}^{+}$-ATPase, and an ATP-dependent $\mathrm{Ca}^{2+}$ uptake activity. In the present study, vesicles were prepared both from the brush border and microsomal membrane fractions of the human placenta to demonstrate possible $\mathrm{Ca}^{2+}$ binding, $\mathrm{Ca}^{2+}-\mathrm{ATP}$ ase, and ATP-dependent $\mathrm{Ca}^{2+}$ uptake activity in the human placenta.

\section{MATERIALS AND METHODS}

\section{PREPARATION OF BRUSH BORDER MEMBRANES}

Brush border membranes were prepared by a modification of the method of Smith and Brush (23) as previously reported (27). Approximately $50 \mathrm{~g}$ of washed placental tissue was minced and placed in $300 \mathrm{ml}$ iced buffer containing $140 \mathrm{mM} \mathrm{NaCl}-10 \mathrm{mM}$ Tris- $\mathrm{HCl}$ ( $\mathrm{pH} 7.2$ ). The tissue was stirred with a magnetic stir bar at $4^{\circ} \mathrm{C}$ for $30 \mathrm{~min}$. After filtering the tissue and medium through cheesecloth, the medium was centrifuged at $15,000 \times g$ for $20 \mathrm{~min}$. The supernatant was decanted and centrifuged at $100,000 \times g$ for $60 \mathrm{~min}$. The pellet obtained was then homogenized in iced isotonic sucrose-Tris buffer with a Potter homogenizer with a Teflon pestle and centrifuged at $15,000 \times g$ for $15 \mathrm{~min}$. This produced a pellet containing two distinct layers. The upper fraction consisted of a loosely packed white layer which contained the brush border membranes. This membrane was collected, resuspended by gentle homogenization, and diluted to final protein concentrations between 3 to $5 \mathrm{mg} / \mathrm{ml}$. By electron microscopic examination,this preparation consisted primarily of spherical membrane vesicles as previously reported with no apparent mitochondrial contaminants (27).

\section{MICROSOMAL MEMBRANE PREPARATION}

The microsomal membrane fraction was prepared as previously described (27) except that EDTA was omitted from buffer solutions. Placentas were obtained with maternal consent immediately 
following term, normal vaginal deliveries and placed on ice. Decidual tissue was removed, and placental fragments were scraped from the fetal vascular tree with a dull scalpel and washed extensively in iced buffer containing $250 \mathrm{mM}$ sucrose- $10 \mathrm{mM}$ Tris$\mathrm{HCl}(\mathrm{pH} \mathrm{7.2)}$. Approximately $20 \mathrm{~g}$ of washed tissue was homogenized with a Tekmar tissuemizer in $200 \mathrm{ml}$ of sucrose buffer at $4^{\circ} \mathrm{C}$ by four ten-sec bursts. The homogenate was poured through four layers of cheesecloth and centrifuged at $15,000 \times g$ for 15 $\mathrm{min}$. The supernatant was centrifuged at $40,000 \times \mathrm{g}$ for $40 \mathrm{~min}$. The pellet obtained was resuspended by gentle homogenization in $100 \mathrm{ml}$ iced buffer and centrifuged again at $40,000 \times \mathrm{g}$ for $40 \mathrm{~min}$. This washed pellet was resuspended in $250 \mathrm{mM}$ sucrose- $10 \mathrm{mM}$ Tris- $\mathrm{HCl}(\mathrm{pH} \mathrm{7.2)}$ to a final membrane protein content of 3 to 5 $\mathrm{mg} / \mathrm{ml}$ by the method of Lowry et al. (11). Samples were assayed for $\mathrm{Ca}^{2+}$ uptake on the day of preparation or within three days after freezing in dry ice-acetone bath and storage at $-30^{\circ} \mathrm{C}$. Previously thawed samples were discarded. This fraction consisted primarily of spherical membrane vesicles by electron microscopic examination. However, mitochondrial and ribosomal contaminants were also evident.

Marker enzyme analysis was performed as previously described (27). Alkaline phosphatase (EC 3.1.3.1) was determined by hydrolysis of paranitrophenyl phosphate (Sigma Chemical Co., St. Louis, MO) in $2 \mathrm{mM} \mathrm{MgCl}$ and in $20 \mathrm{mM}$ monoethanolamine ( $\mathrm{pH} \mathrm{10.5).} \mathrm{Ca}^{2+}$ and $\mathrm{Mg}^{2+}$-ATPase (EC 3.6.1.3) were determined in the $\mathrm{Ca}^{2+}$ uptake media $(\mathrm{pH} 7.0)$ under $\mathrm{Ca}^{2+}$ uptake conditions or at $\mathrm{pH} 8.1$ under optimal conditions (27) by the liberation of inorganic phosphate determined by the method of Fiske and Subbarow (6). Glutamate dehydrogenase (EC 1.4.1.3) activity was assessed at $24^{\circ} \mathrm{C}$ as previously described (27).

$$
\mathrm{Ca}^{2+} \text { UPTAKE }
$$

Standard $\mathrm{Ca}^{2+}$ uptake was assessed at $30^{\circ} \mathrm{C}$ in a $6 \mathrm{ml}$ final assay volume containing 0.2 to $0.6 \mathrm{mg} / \mathrm{ml}$ membrane protein, $100 \mathrm{mM}$ $\mathrm{KCl}, 20 \mathrm{mM}$ imidazole buffer ( $\mathrm{pH} 7.0), 20 \mathrm{mM}$ sodium azide, 5 $\mathrm{mM}$ oxalic acid, $5 \mathrm{mM}$ Mg-ATP (Sigma Chemical Co.), $0.05 \mathrm{mM}$ $\mathrm{CaCl}_{2}$, and ${ }^{45} \mathrm{CaCl}_{2}(0.1$ to $4.0 \mu \mathrm{Ci} / \mathrm{ml}$ ) (New England Nuclear, Boston, MA). The specific activity of ${ }^{45} \mathrm{Ca}^{2+}$ was kept constant during experiments in which increasing concentrations of $\mathrm{CaCl}_{2}$ were required. After preincubation at $30^{\circ} \mathrm{C}$ for $10 \mathrm{~min}$, the reaction was initiated by the addition of membrane protein $(300 \mu l)$. Aliquots were removed immediately and every two min for 10 to $20 \mathrm{~min}$ and filtered under negative pressure through Millipore filters. The filters were washed four times with $1-\mathrm{ml}$ aliquots of iced isotonic sucrose buffer, dried at room temperature, and counted in Aquasol (New England Nuclear). An aliquot of the incubation media was also spotted on a Millipore filter, dried, and counted under identical conditions. Uptake rates were estimated from at least six points for each uptake experiment and analyzed in relation to final membrane protein concentration $(0.2$ to 0.6 $\mathrm{mg} / \mathrm{ml}$ ). Binding in the absence of ATP was complete by $2 \mathrm{~min}$ and was subtracted to give ATP-dependent accumulation values. Contaminant calcium was similar in microsomal and brush border fractions and was approximately $0.005 \mathrm{mM}$ elemental calcium as determined by flame spectroscopy in the final membrane preparation. All ligands and reactants were buffered prior to addition to the assay and varied as described in individual experiments.

Maximal uptake was always observed in freshly prepared vesicles within several $\mathrm{hr}$ after preparation. Vesicles stored at $2^{\circ} \mathrm{C}$ lost activity rapidly and were devoid of ATP-dependent $\mathrm{Ca}^{2+}$ uptake activity after two days. Samples which were rapidly frozen and stored at $-30^{\circ} \mathrm{C}$ retained 50 to $70 \%$ of the starting activity for at least one wk. Experiments were performed on the day following preparation, unless otherwise noted. Boiling the sample assay at $60^{\circ} \mathrm{C}$, and multiple freeze-thaw cycles each abolished uptake activity.

\section{VESICULAR SPACE}

Fresh brush border and microsomal vesicles were incubated with 1 to $10 \mathrm{mM}$, 3-O-methyl-D-glucose (Sigma Chemical Co.) and $\left[{ }^{3} \mathrm{H}\right] 3-O$-methyl-D-glucose $(2 \mu \mathrm{Ci} / \mathrm{ml})$ (New England $\mathrm{Nu}$ clear). The vesicular space was determined as described by Kletzien et al. (9) after Millipore filtration and wash in iced isotonic buffer containing $1 \mathrm{mM}$ phloridzin (Sigma Chemical Co.).

\section{$\mathrm{Ca}^{2+}$-EGTA BUFFER SYSTEM}

Free $\mathrm{Ca}^{2+}$ concentrations during these uptake experiments were estimated from the reaction conditions in relation to $\mathrm{Ca}^{2+}, \mathrm{Mg}^{2+}$, $\mathrm{K}^{+}$, ATP, and 0.5 or $1.0 \mathrm{mM}$ EGTA at $\mathrm{pH} \mathrm{7.0.} \mathrm{The} \mathrm{affinity}$ constants and equations used for these calculations have been previously reported by Potter and Gergely (17).

\section{RESULTS}

Calcium uptake by microsomal and brush border vesicles was dependent on ATP and magnesium and was enhanced by the addition of a trapping ion such as phosphate or oxalate (Fig. 1). In the absence of ATP, Ca ${ }^{2+}$ was rapidly "bound" by the membrane in a process which was complete within 2 min at $30^{\circ} \mathrm{C}$ and was proportional to membrane protein. However, in the presence of ATP and $\mathrm{Mg}^{2+}$, calcium was rapidly accumulated by the vesicles in a process linearly dependent upon membrane protein, between 0.2 and $0.6 \mathrm{mg} / \mathrm{ml}$. Equilibrium was established within $15 \mathrm{~min}$ (Fig. 2) and was maintained up to $60 \mathrm{~min}$. The initial uptake rates $(0$ to $10 \mathrm{~min}$ ) were nearly linear in the presence of phosphate or oxalate, and the uptake rates were therefore esti-
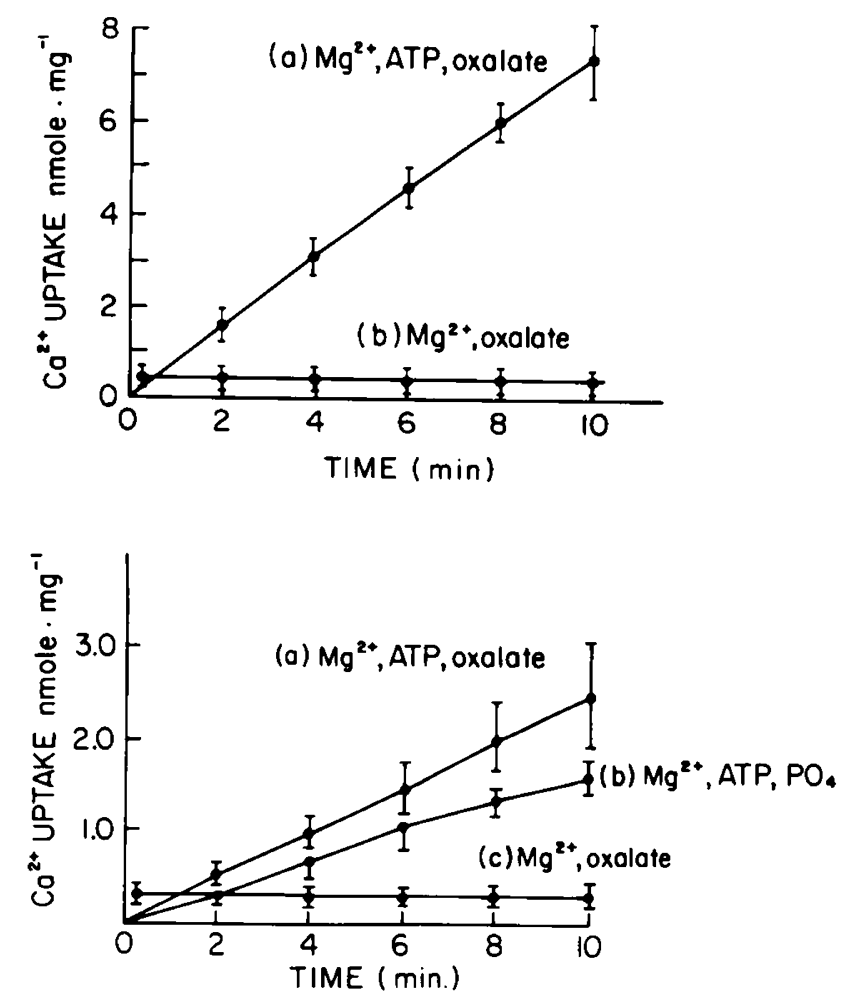

Fig. 1. Time course of ATP-dependent $\mathrm{Ca}^{2+}$ uptake by $\mathrm{A}$, microsomal and $B$, microvillus placental fractions. The $\mathrm{Ca}^{2+}$ uptake by frozen placental fractions was assessed in a standard assay containing $50 \mu \mathrm{M} \mathrm{CaCl}_{2},{ }^{45} \mathrm{CaCl}_{2}$ $(0.5 \mu \mathrm{Ci} / \mathrm{ml}), 5 \mathrm{mM} \mathrm{MgCl}, 5 \mathrm{mM} \mathrm{ATP}, 10 \mathrm{mM}$ sodium azide, $5 \mathrm{mM}$ oxalate or phosphate, and $20 \mathrm{mM}$ imidazole $\left(\mathrm{pH} \mathrm{7.0)} . \mathrm{Ca}^{2+}\right.$ binding in the absence of ATP was subtracted from uptake in the presence of ATP to give uptake values. The reaction was initiated by additions of membrane fraction and was terminated by rapid filtration through Millipore filters. Phosphate was as effective as oxalate in enhancing $\mathrm{Ca}^{2+}$ uptake in the microsomal fraction. Values represent the mean \pm S.D. of ten placental preparations for each fraction. $\mathrm{Ca}^{2+}$ uptake was entirely ATP dependent in both membrane fractions and increased nearly linearly between 2 and $10 \mathrm{~min}$. The specific activity was always higher in the microsomal fraction as compared to the brush border fraction. 
mated from the slope of the 0 to 10 min uptake curve for each determination of rate. The rate of $\mathrm{Ca}^{2+}$ uptake by fresh microsomal and brush border vesicles was approximately double that of oncefrozen vesicles. Kinetic characteristics and requirements of $\mathrm{Ca}^{2+}$ uptake were similar in both membrane fractions, and no distinct property was found which distinguished microsomal from brush border $\mathrm{Ca}^{2+}$ uptake except for the lower activity in the latter.

The vesicular nature of the uptake process was demonstrated by performing the incubation in increasing concentrations of sucrose which theoretically reduced the vesicular volume. $\mathrm{Ca}^{2+}$ uptake was inversely related to increasing sucrose concentration (Fig. 3). The vesicular space of these preparations was estimated from the equilibration of 3-O-methyl-D-glucose with fresh brush border and microsomal vesicles. Brush border vesicular space was not different from that of the microsomal fraction, and spaces were, respectively, $3.95 \pm 0.32$ and $4.08 \pm 0.11 \mu \mathrm{l} / \mathrm{mg}$ protein (mean \pm S.D.; $n=4$ ). Thus, in the present study, at equilibrium, $\mathrm{Ca}^{2+}$ was accumulated within the vesicles up to 100 -fold greater than the concentration present in the medium. Further support for the vesicular nature of the uptake was the finding that $\mathrm{Ca}^{2+}$ uptake was enhanced by trapping ligands such as oxalate or phosphate and that uptake activity was destroyed by conditions which might disrupt vesicle formation such as heating, freezethaw cycles, and storage at $2^{\circ} \mathrm{C}$.

\section{SUBCELLULAR DISTRIBUTION}

Calcium uptake activity was enriched approximately six-fold in the microsomal fraction above that in the crude homogenate,

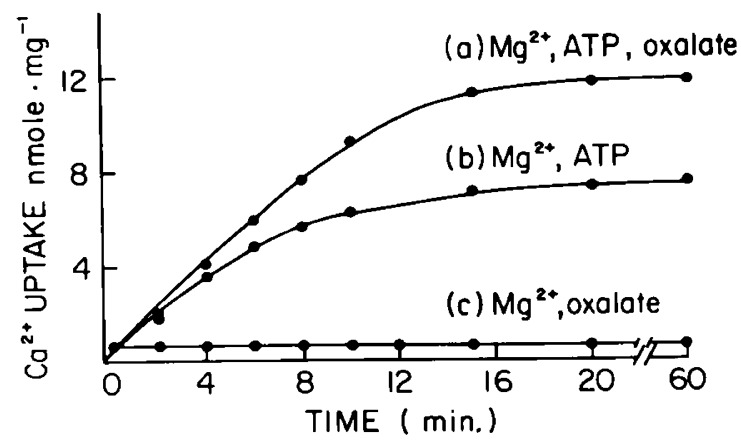

Fig. 2. Time course of $\mathrm{Ca}^{2+}$ uptake in microsomal placental membranes with or without ATP or oxalate. $\mathrm{Ca}^{2+}$ uptake was assessed in the standard assay as described in "Materials and Methods" at $30^{\circ} \mathrm{C}$. $a$, presence of $\mathrm{Mg}^{2+}, 5 \mathrm{mM}$ oxalate, and $5 \mathrm{mM} \mathrm{ATP} ; b, 5 \mathrm{mM} \mathrm{ATP}$ and $\mathrm{Mg}^{2+}$; and $c$, oxalate and $\mathrm{Mg}^{2+}$ in the absence of ATP. $\mathrm{Ca}^{2+}$ uptake reached equilibrium after $20 \mathrm{~min}$ and remained stable for up to $60 \mathrm{~min}$. ATP-dependent uptake was enhanced by oxalate. Further addition of ATP ( $10 \mathrm{mM}$ final concentration) at $20 \mathrm{~min}$ did not further enhance uptake. Curves, experiments from four separate placental preparations. whereas it was only slightly enriched in the brush border fraction as represented by Table 1 . Because the vesicular volumes were similar in microsomal and brush border fractions, the enrichment values for $\mathrm{Ca}^{2+}$ uptake are likely to represent differences in the intrinsic $\mathrm{Ca}^{2+}$ pump activities of these membrane preparations; however, differences related to the orientation or "sidedness" of the $\mathrm{Ca}^{2+}$ pump were not clarified in these experiments.

$\mathrm{Ca}^{2+}$ uptake was not coenriched with $\mathrm{Ca}^{2+}$-stimulated ATPase or alkaline phosphatase activity during subcellular fractionation. These latter activities were best enriched in the brush border membranes. Mitochondrial contamination was assessed with the marker enzyme glutamate dehydrogenase, which was present in microsomal but absent from brush border fractions. However, azide and oligomycin, which are known potent inhibitors of mitochondrial $\mathrm{Ca}^{2+}$ uptake, had no effect on $\mathrm{Ca}^{2+}$ uptake in either placental fraction. Nevertheless, $10 \mathrm{mM}$ azide was added to the uptake media during all experiments to control for a possible mitochondrial contribution to $\mathrm{Ca}^{2+}$ uptake.

\section{RELATIONSHIP OF UPTAKE TO FREE Ca ${ }^{2 *}$}

The rate of ATP-dependent $\mathrm{Ca}^{2+}$ uptake was nonlinearly related to the free $\mathrm{Ca}^{2+}$ concentration in both microsomal and brush border fractions (Fig. 4). Free $\mathrm{Ca}^{2+}$ concentration was varied with a $\mathrm{Ca}^{2+}$-EGTA buffer system between 0.11 and $62.9 \times 10^{-8}$ free $\mathrm{Ca}^{2+}$. Under these conditions, the uptake process was saturable with respect to free $\mathrm{Ca}^{2+}$. Data from such experiments were fit directly to the equation $V=\frac{V_{\max } S}{S+K_{m}}$ using nonlinear regression

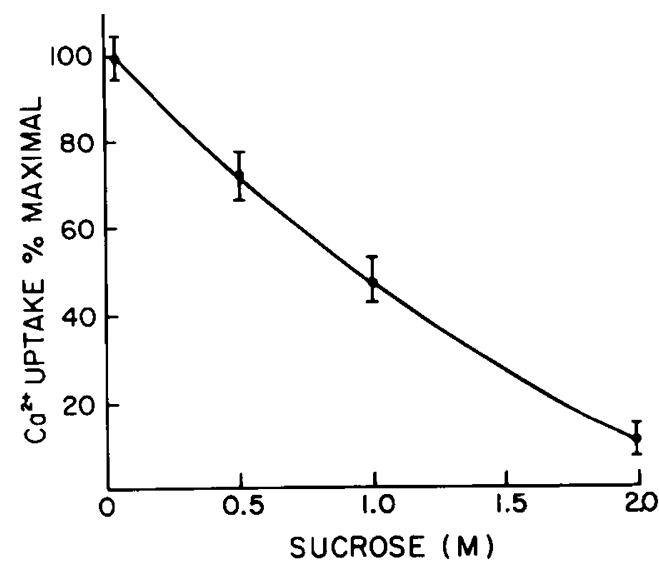

Fig. 3. ATP-dependent $\mathrm{Ca}^{2+}$ uptake in relation to osmolality (sucrose). Increasing concentrations of sucrose were added to standard $\mathrm{Ca}^{2+}$ uptake assay with microsomal membrane to final concentrations $(0.1$ to $2.0 \mathrm{mM})$ sucrose. The reaction was terminated by rapid filtration at $20 \mathrm{~min}$. Points, mean \pm S.D. of triplicate determinations at each concentration. $\mathrm{Ca}^{2+}$ uptake varied inversely with the osmolality and therefore positively with increasing vesicular space.

Table 1. Distribution of $\mathrm{Ca}^{2+}$ uptake, $\mathrm{Ca}^{2+}-$ ATPase, and marker enzymes in placental fractions ${ }^{1}$

\begin{tabular}{|c|c|c|c|c|c|c|}
\hline Fraction & $\begin{array}{c}\mathrm{Ca}^{2+} \text { uptake } \\
\text { oxalate } \\
(\mathrm{nmole} / \mathrm{mg} / \mathrm{min})\end{array}$ & $\begin{array}{c}\mathrm{Ca}^{2+} \text { uptake } \\
\text { phosphate } \\
\text { (nmole/mg/min) }\end{array}$ & $\begin{array}{c}\mathrm{Ca}^{2+}-\mathrm{ATPase} \\
(\mathrm{pH} \mathrm{8.1)} \\
(\mu \mathrm{mole} / \mathrm{mg} / \mathrm{min})\end{array}$ & $\begin{array}{c}\text { Alkaline } \\
\text { phosphatase } \\
(\mu \text { mole } / \mathrm{mg} / \mathrm{min})\end{array}$ & $\begin{array}{c}\text { Glutamate } \\
\text { dehydrogenase } \\
(\mu \text { mole } / \mathrm{mg} / \mathrm{min})\end{array}$ & $\begin{array}{c}\text { Total ATPase } \\
(\mu \mathrm{mole} / \mathrm{mg} / \mathrm{min})\end{array}$ \\
\hline Whole & $1.44 \pm 0.02^{2}$ & $\mathrm{ND}^{3}$ & $0.13 \pm 0.03$ & $0.25 \pm 0.04$ & $0.015 \pm 0.005$ & ND \\
\hline Microsomal & $7.4 \pm 0.82$ & $7.01 \pm 1.2$ & $0.59 \pm 0.15$ & $1.33 \pm 0.39$ & $0.016 \pm 0.004$ & $0.156 \pm 0.01$ \\
\hline Brush border & $2.37 \pm 0.71$ & $1.6 \pm 0.18$ & $1.46 \pm 0.16$ & $3.20 \pm 0.30$ & $<0.001$ & $0.164 \pm 0.02$ \\
\hline
\end{tabular}

${ }^{1}$ Distribution of $\mathrm{Ca}^{2+}$ uptake, $\mathrm{Ca}^{2+}$-ATPase, alkaline phosphatase, and glutamate dehydrogenase in placental fractions. $\mathrm{Ca}^{2+}$ uptake activity was assessed in each fraction at $30^{\circ} \mathrm{C}$ in ten placental preparations under standard assay conditions ( $\left.\mathrm{pH} 7.0\right)$ as described in "Materials and Methods"; 5 $\mathrm{mM}$ phosphate was substituted for $5 \mathrm{mM}$ oxalate as indicated. $\mathrm{Ca}^{2+}$-ATPase and alkaline phosphatase were determined under optimal conditions $(\mathrm{pH}$ 8.1 and 10.5 , respectively) at $37^{\circ} \mathrm{C}$. Total ATPase was assessed under standard uptake conditions at $\mathrm{pH} 7.0$ in the presence of $50 \mu \mathrm{M} \mathrm{CaCl}, 10 \mathrm{mM}$ azide, $5 \mathrm{mM}$ oxalate, and $5 \mathrm{mM} \mathrm{Mg-ATP}$. The addition of $100 \mu \mathrm{M}$ EGTA in the presence of $100 \mu \mathrm{M} \mathrm{CaCl}_{2}$ did not inhibit ATPase activity nor did the addition of $\mathrm{CaCl}_{2}(100 \mu \mathrm{M})$ stimulate $\mathrm{Mg}^{2+}$-ATPase in at least 10 experiments with six separate placental preparations.

Mean \pm S.D.

${ }^{3} \mathrm{ND}$, not done. 

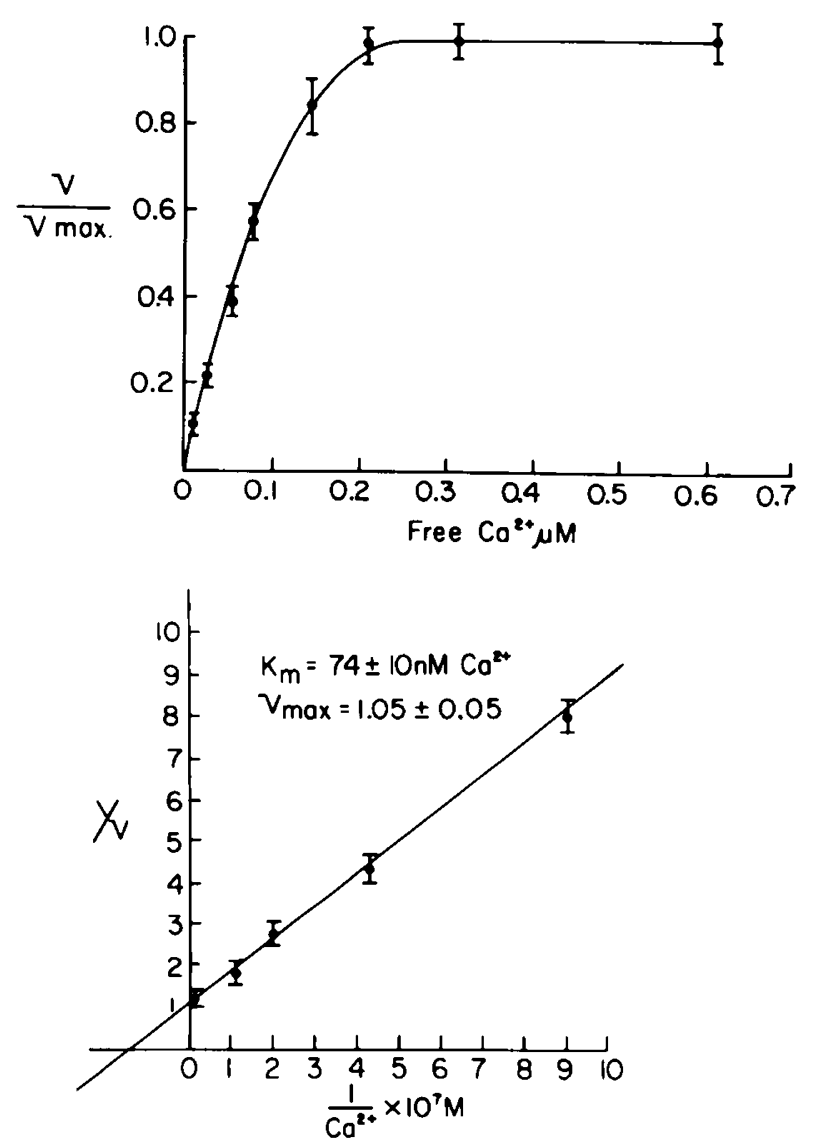

Fig. 4. ATP-dependent $\mathrm{Ca}^{2+}$ uptake in relation to estimated free $\mathrm{Ca}^{2+}$. Free $\mathrm{Ca}^{2+}$ was regulated by addition of 0.5 or $1.0 \mathrm{mM}$ EGTA to the standard uptake assay in the presence of $5 \mathrm{mM}$ phosphate. Increasing $\mathrm{CaCl}_{2}(0.050$ to $1.0 \mathrm{mM})$ was added to vary free $\mathrm{Ca}^{2+}$ from 0.11 to 62.8 $\times 10^{-8} \mathrm{M}$. The specific activity of $\mathrm{CaCl}_{2}$ was maintained constant, and the uptake rate at each $\mathrm{Ca}^{2+}$ concentration was determined from at least six data points from four separate microsomal membrane preparations. The free $\mathrm{Ca}^{2+}$ kinetic values were calculated as described in "Materials and Methods." The data from $A$ were analyzed as described in "Materials and Methods"; $B$, Lineweaver-Burke plot from these data. ATP-dependent $\mathrm{Ca}^{2+}$ uptake was a saturable process dependent on free $\mathrm{Ca}^{2+}$ concentrations.

curve fitting procedures as suggested by Wilkinson (29). The $K_{m}$ for free $\mathrm{Ca}^{2+}$ was $74 \pm 10 \mathrm{nM}$ in the microsomal fraction and 50 $\pm 6 \mathrm{nM}$ in the brush border fraction; $V_{\max }$ was $1.05 \pm 0.046$ $\mathrm{nmole} / \mathrm{mg}$ and $0.2 \pm 0.01 \mathrm{nmole} / \mathrm{mg} / \mathrm{min}$, respectively (mean \pm S.D.; $n=4)$. High concentrations of $\mathrm{Ca}^{2+}$ (greater than $1 \mathrm{mM}$ ) always resulted in an inhibition of uptake activity.

\section{MAGNESIUM}

$\mathrm{Ca}^{2+}$ uptake in both fractions was highly dependent on $\mathrm{Mg}^{2+}$ (Fig. 5). ATP-dependent $\mathrm{Ca}^{2+}$ uptake was not supported in the absence of $\mathrm{Mg}^{2+}$ in either fraction, nor did the addition of increasing concentrations of $\mathrm{CaCl}_{2}(0.50$ to $5.0 \mathrm{mM})$ support ATP-dependent $\mathrm{Ca}^{2+}$ uptake. Maximal $\mathrm{Ca}^{2+}$ uptake was observed at $5 \mathrm{mM}$ $\mathrm{MgCl}_{2}$ in the presence of $5 \mathrm{mM}$ ATP. Higher $\mathrm{Mg}^{2+}$ concentrations $(10 \mathrm{mM})$ did not further enhance $\mathrm{Ca}^{2+}$ uptake. Half-maximal activation was noted at approximately $1.25 \mathrm{mM} \mathrm{Mg}^{2+}$ under standard assay conditions.

\section{NUCLEOTIDE REQUIREMENTS}

$\mathrm{Ca}^{2+}$ uptake was best supported in both fractions by ATP as compared to other nucleotides. However, ADP, AMP, and GTP $(5 \mathrm{mM})$ also supported $\mathrm{Ca}^{2+}$ uptake in the absence of ATP under standard assay conditions. The fraction of uptake for each nucleo- tide in relation to the rate observed in $5 \mathrm{mM}$ ATP was ADP = $0.35 \pm 0.14$, AMP $=0.25 \pm 0.08$, and GTP $=0.25 \pm 0.07$ (mean \pm S.D.) in five $\mathrm{Ca}^{2+}$ uptake experiments with the microsomal fraction.

\section{PH DEPENDENCY}

The pH dependency of $\mathrm{Ca}^{2+}$ uptake and $\mathrm{Ca}^{2+}-\mathrm{ATPase}$ activity is represented by Figure 6. Maximal $\mathrm{Ca}^{2+}$ uptake in brush border and microsomal fractions was observed between 6.5 and 7.0 . In contrast, the $\mathrm{pH}$ optimum of $\mathrm{Ca}^{2+}$-ATPase activity was $\mathrm{pH} 8.1$. At this $\mathrm{pH}, \mathrm{Ca}^{2+}$ uptake was markedly inhibited.

\section{TEMPERATURE}

The time course of the ATP-dependent $\mathrm{Ca}^{2+}$ uptake process was assessed at $2,10,20,30,37$, and $60^{\circ} \mathrm{C}$. Uptake was abolished at 2 and $60^{\circ} \mathrm{C}$. The reaction was highly temperature dependent: maximal uptake rates were noted at $37^{\circ} \mathrm{C}$ and approximately doubled for each $10^{\circ} \mathrm{C}$ increment above $2^{\circ} \mathrm{C}$.

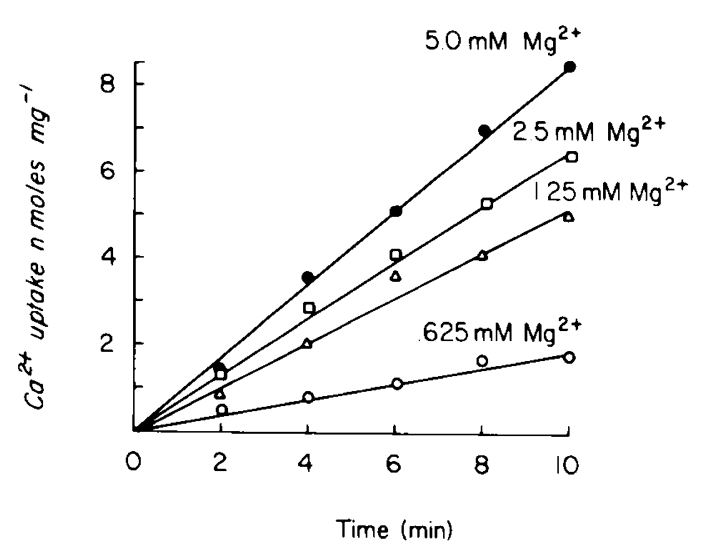

Fig. 5. Magnesium dependency of ATP-dependent $\mathrm{Ca}^{2+}$ uptake. $\mathrm{Ca}^{2+}$ uptake was assessed in the standard assay with microsomal membrane in the presence of $5 \mathrm{mM}$ oxalate. Magnesium was varied from (0 to $5 \mathrm{mM}$ ) by the addition of $\mathrm{MgCl}_{2}$. Maximal $\mathrm{Ca}^{2+}$ uptake was demonstrated at 5 $\mathrm{mM} \mathrm{MgCl}_{2}$, and higher final concentrations did not further enhance uptake.

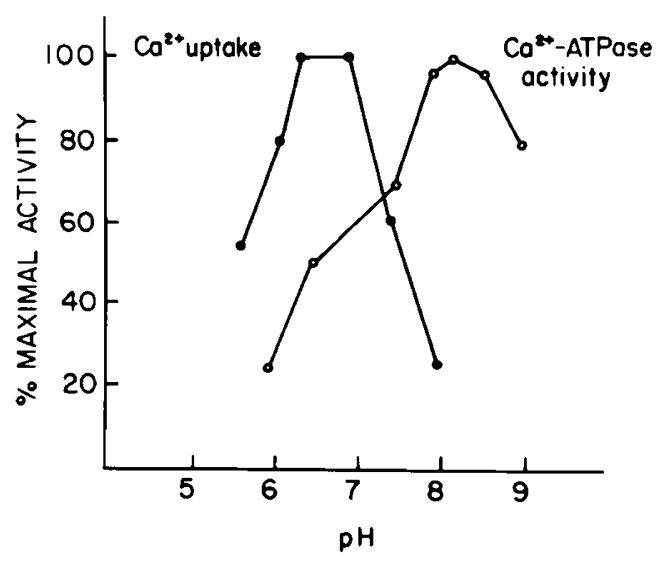

Fig. 6. The $\mathrm{pH}$ dependency of ATP-dependent $\mathrm{Ca}^{2+}$ uptake and $\mathrm{Ca}^{2+}$ ATPase. The $\mathrm{pH}$ of the assay medium was adjusted between 6.0 and 9.5 . $\mathrm{Ca}^{2+}$ uptake was determined under standard assay conditions at $30^{\circ} \mathrm{C}$ in both fractions in four separate experiments at each $\mathrm{pH} . \mathrm{Ca}^{2+}-\mathrm{ATPase}$ was assessed at $37^{\circ} \mathrm{C}$ by determination of inorganic phosphate as described in "Materials and Methods." The $\mathrm{pH}$ dependency of $\mathrm{Ca}^{2+}$ uptake was identical in brush border and microsomal fractions. The $\mathrm{pH}$ maximum of $\mathrm{Ca}^{2+}$ uptake was 6 to 7 and contrasted with the $\mathrm{pH}$ maximum of $\mathrm{Ca}^{2+}$. stimulated ATPase ( $\mathrm{pH} \mathrm{8.1)}$. 


\section{INHIBITORS AND THE EFFECTS OF OTHER LIGANDS}

The effects of various agents on ATP-dependent $\mathrm{Ca}^{2+}$ uptake were assessed in at least four experiments with each agent in the microsomal fraction. Ethacrynic acid, which nonspecifically binds membrane-bound sulfhydryl groups, was a potent inhibitor of ATP-dependent $\mathrm{Ca}^{2+}$ uptake in both fractions; $50 \%$ inhibition was noted at $1 \mathrm{mM}$ ethacrynic acid. In contrast, placental $\mathrm{Ca}^{+2}-\mathrm{ATPase}$ was only minimally inhibited by $1 \mathrm{mM}$ ethacrynic acid $(10 \%)$. Azide $(10 \mathrm{mM})$ and oligomycin $(1 \mu \mathrm{g} / \mathrm{ml})$, which are effective inhibitors of mitochondrial $\mathrm{Ca}^{2+}$ uptake, had no effect on microsomal and brush border membrane $\mathrm{Ca}^{2+}$ uptake. DL-Phenylalanine $(5 \mathrm{mM})$ markedly inhibited placental alkaline phosphatase (approximately $50 \%)$ but did not alter $\mathrm{Ca}^{2+}$ uptake. Ouabain $\left(10^{-3}\right.$ $M)$, ruthinium red, $\left(10^{-5} \mathrm{M}\right)$ strontium $(0.1$ to $1.0 \mathrm{mM})$, and manganese $(0.02$ to $0.1 \mathrm{mM})$ also had no effect on $\mathrm{Ca}^{2+}$ uptake. Likewise, the substitution of $100 \mathrm{mM} \mathrm{NaCl}$ in the assay medium did not alter $\mathrm{Ca}^{2+}$ uptake in either fraction. Prostaglandins $\mathrm{E}_{1}, \mathrm{E}_{2}$, and $F_{2 \alpha}\left(10^{-5} \mathrm{M}\right)$ had no effect on $\mathrm{Ca}^{2+}$ uptake when added directly to the incubation media. Dibutyryl cyclic adenosine monosphosphate ( $1 \mathrm{mM}$ ) also had no effect on $\mathrm{Ca}^{2+}$ uptake.

$$
\mathrm{Ca}^{2+}-\mathrm{ATPase}
$$

$\mathrm{Ca}^{2+}$-stimulated ATPase was determined in each fraction under optimal conditions ( $\mathrm{pH} 8.1$ ) and during $\mathrm{Ca}^{2+}$ uptake experiments (pH 7.0). $\mathrm{Ca}^{2+}$-stimulated ATPase activity was 10-fold enriched in the brush border fraction and four-fold enriched in the microsomal fraction. Such $\mathrm{Ca}^{2+}-\mathrm{ATPase}$ was not $\mathrm{Mg}^{2+}$ dependent in the presence of $5 \mathrm{mM} \mathrm{CaCl}_{2}$ and $5 \mathrm{mM}$ ATP. The apparent $\mathrm{K}_{\mathrm{m}}$ for $\mathrm{CaCl}_{2}$ was $0.37 \pm 0.02 \mathrm{mM}$ (mean \pm S.D.) in the presence of $5 \mathrm{mM}$ ATP from four placental preparations under these conditions. The total ATPase activity also determined during the $\mathrm{Ca}^{2+}$ uptake experiments and was approximately $0.17 \pm 0.02 \mu \mathrm{mole} /$ $\mathrm{mg} / \mathrm{min}$ in the microsomal fraction. $\mathrm{Ca}^{2+}$-stimulated, $\mathrm{Mg}^{2+}$-dependent ATPase could not be demonstrated in the microsomal fraction under a variety of assay conditions designed to elicit such activity.

\section{$\mathrm{Ca}^{2+}$ BINDING TO PLACENTAL MEMBRANES}

Non-ATP-dependent $\mathrm{Ca}^{2+}$ binding increased with the calcium concentration in the assay to increasing microsomal and brush border protein concentration (Fig. 7). Binding was rapid at $30^{\circ} \mathrm{C}$ and was completed within $2 \mathrm{~min}$. The specific activity of nonATP-dependent $\mathrm{Ca}^{2+}$ binding was always higher in the microsomal as compared to brush border fractions. The binding of $\mathrm{Ca}^{2+}$ to the microsomal fraction increased as a "complex function" of free $\mathrm{Ca}^{2+}$ and was not saturable at free $\mathrm{Ca}^{2+}$ concentrations up to $3 \mathrm{mM}$. Ca ${ }^{2+}$ binding to brush border membranes also increased with increasing $\mathrm{Ca}^{2+}$; these binding sites were also not saturated up to $3 \mathrm{mM} \mathrm{Ca}^{2+}$.

\section{DISCUSSION}

In the present study, it has been demonstrated that (1) vesicles prepared from membrane fractions of human placenta both bind $\mathrm{Ca}^{2+}$ and contain an ATP-dependent $\mathrm{Ca}^{2+}$ sequestration activity; (2) ATP-dependent $\mathrm{Ca}^{2+}$ uptake is dependent upon temperature and $\mathrm{Mg}^{2+}$ and is enhanced by trapping ligands such as oxalate and phosphate; (3) the process is saturable at low $\mathrm{Ca}^{2+}$ concentrations. Because of the low $\mathrm{K}_{n}\left(10^{-7}\right.$ to $\left.10^{-8} \mathrm{M} \mathrm{Ca}^{2+}\right)$, it is suggested that it might be activated by low $\mathrm{Ca}^{2+}$ concentrations, such as would be expected within the cytosol of the syncytium; (4) ATP. dependent $\mathrm{Ca}^{2+}$ uptake is maximally enriched in the microsomal placental fraction in comparison to the activity in purified brush border membranes; and finally (5) uptake is not associated with $\mathrm{Ca}^{2+}$-stimulated ATPase which is most highly enriched in brush border membranes.

The asymmetrical transport of $\mathrm{Ca}^{2+}$ from the mother to fetus is likely to occur transcellularly across the syncytium. Large quantities of $\mathrm{Ca}^{2+}$ move from the mother to fetus at extracellular free $\mathrm{Ca}^{2+}$ concentrations which are in excess of $10^{-3} \mathrm{M}$. However,

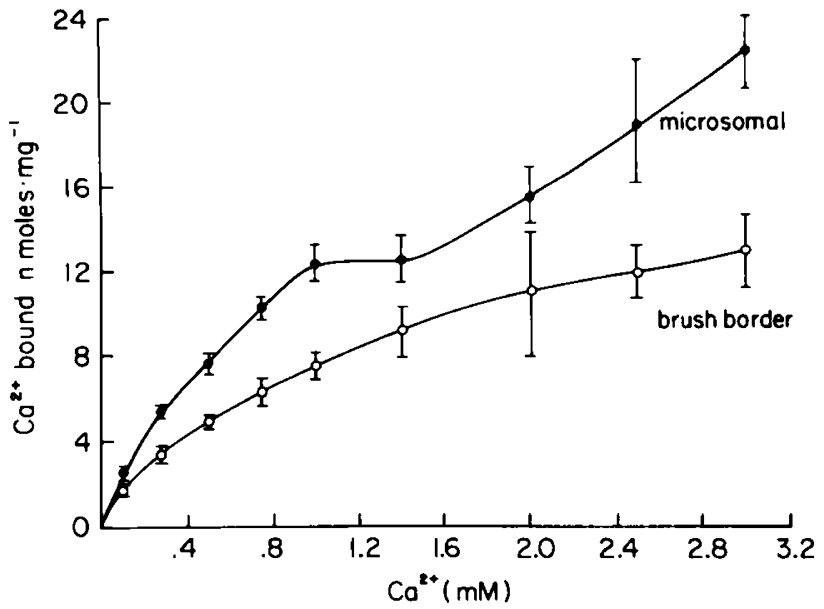

Fig. 7. Non-ATP-dependent $\mathrm{Ca}^{2+}$ binding to brush border and microsomal placental membrane. $\mathrm{Ca}^{2+}$ binding was determined under standard assay conditions (phosphate) with the omission of both ATP and oxalate. The incubation was terminated by rapid filtration at $20 \mathrm{~min}$ at $30^{\circ} \mathrm{C}$. The $\mathrm{Ca}^{2+}$ concentration was varied by the addition of $\mathrm{CaCl}_{2}$ to final concentrations $(0.1$ to $3.0 \mathrm{mM}) \mathrm{CaCl}_{2}$. Points, mean \pm S.D. of triplicate determinations from five separate brush border and microsomal preparations. Non-ATP-dependent $\mathrm{Ca}^{2+}$ binding was higher in microsomal than brush border membrane. Binding varied as a complex function of $\mathrm{Ca}^{2+}$ and was not saturable up to $3 \mathrm{mM}$ added $\mathrm{CaCl}_{\mathbf{k}}$.

intracellular $\mathrm{Ca}^{2+}$ is generally maintained at concentrations which are much lower than extacellular $\mathrm{Ca}^{2+}$. The molecular mechanisms which might be involved in intracellular $\mathrm{Ca}^{2+}$ regulation and in $\mathrm{Ca}^{2+}$ transport in the placenta are unclear at present but may include passive transcellular diffusion, binding to subcellular fractions, or energy-dependent uptake by subcellular elements as have been suggested in other epithelial $\mathrm{Ca}^{2+}$ transport systems (25). A rational hypothesis regarding the molecular mechanism of transplacental $\mathrm{Ca}^{2+}$ transport should include a mechanism by which intracellular placental $\mathrm{Ca}^{2+}$ is regulated at low concentrations $\left(10^{-7}\right.$ to $\left.10^{-\gamma} \mathrm{M}\right)$. Thus, $\mathrm{Ca}^{2+}$ may enter the syncytium by passive diffusion down a chemical gradient or by a mechanism which involves $\mathrm{Ca}^{2+}$ binding to cell membrane which is subsequently internalized. Once within the cell, its concentration may be (1) regulated by its binding to intracellular sites such as to placental calcium binding protein which has been recently described in rat placental cytosol (1); (2) sequestered within membrane-bound structures such as vesicles, mitochondria, or other intracellular organelles; (3) regulated by its exit from the cell either by exocytosis or by being actively pumped to the fetus at the trophoblastic basement membrane (against a concentration gradient) by a plasma membrane-bound $\mathrm{Ca}^{2+}$ pump. The ATP-dependent $\mathrm{Ca}^{2+}$ pump activity presently described might be hypothesized to play a role in such energy-dependent intracellular $\mathrm{Ca}^{2+}$ sequestration or "pumping" at the fetal-placental interface.

ATP-dependent $\mathrm{Ca}^{2+}$ pump activity can be demonstrated in numerous tissues, and the characteristics of the $\mathrm{Ca}^{2+}$ uptake in placental vesicles described in the present studies are similar in many respects to those described in other tissues $(10,13,14,19$, 24). The $\mathrm{K}_{\mathrm{m}}$ for free $\mathrm{Ca}^{2+}$ demonstrated in the present study is extremely low, although there is some disagreement in the estimation of free $\mathrm{Ca}^{2+}$ in the presence of EGTA and ATP (the $\mathrm{K}_{\mathrm{m}}$ is approximately five-fold higher when estimated with the calculations as described by Katz et al. (8). Nevertheless, the $\mathbf{K}_{m}$ is low by either calculation, and it is therefore likely that the ATPdependent $\mathrm{Ca}^{2+}$ uptake activity is activated by low calcium concentrations, as would be expected within the cytosol of the syncytium.

The characteristics of placental $\mathrm{Ca}^{2+}$ uptake are similar to those of $\mathrm{Ca}^{2+}$ uptake activities in liver (14), kidney (15), and intestine (7), but contrast sharply to $\mathrm{Ca}^{2+}$ uptake described in a report on 
guinea pig placental membranes as assessed by stop flow dialysis (20). Human placental $\mathrm{Ca}^{2+}$ uptake was saturable with respect to free $\mathrm{Ca}^{2+}$ and displayed Michaelis-Menten like kinetics with respect to free $\mathrm{Ca}^{2+}$. Furthermore, uptake required $\mathrm{Mg}^{2+}$ and ATP and was highly $\mathrm{pH}$ dependent (maximum 7.0 ). In contrast, the $\mathrm{Ca}^{2+}$ uptake of guinea pig placental membranes did not require $\mathrm{Mg}^{2+}$, was stimulated by $\mathrm{Mg}^{2+}$ at low $\mathrm{Ca}^{2+}$ concentration, and did not appear to be a saturable process (20).

\section{CELLULAR LOCALIZATION}

The precise cellular localization of the $\mathrm{Ca}^{2+}$ uptake system is complicated by the numerous cell types present in human placenta. For example, smooth muscle $\mathrm{Ca}^{2+}$ uptake has been previously demonstrated. However, the characteristics of $\mathrm{Ca}^{2+}$ uptake in vesicles from smooth muscle of the umbilical artery are distinct from $\mathrm{Ca}^{2+}$ uptake in placental vesicles (3). The former is highly ATP specific and inactive at $\mathrm{pH}$ less than 7 . In contrast, placental $\mathrm{Ca}^{2+}$ uptake was supported by nucleotides other than ATP and was active at $\mathrm{pH}$ less than 7.0. Thus, it appears unlikely that smooth muscle contamination accounted for the $\mathrm{Ca}^{2+}$ uptake of placental vesicles.

\section{SUBCELLULAR LOCALIZATION}

ATP-dependent $\mathrm{Ca}^{2+}$ uptake activity was most highly enriched in microsomal membrane fractions of the placenta where it was enriched six- to seven-fold above the activity present in a crude placental homogenate. Microsomal membrane is likely to contain membranes from both apical and basilar plasma membranes of the placental as well as membrane from intracellular organelles (22, 26-28). However, the ATP-dependent $\mathrm{Ca}^{2+}$ uptake is not. likely to originate primarily from brush border membranes which in the present study were not highly enriched in $\mathrm{Ca}^{2+}$ uptake activity. This difference in $\mathrm{Ca}^{2+}$ uptake activity between brush border and microsomal fractions could not be explained by differences in vesicular space. The vesicular space in each fraction was similar and in agreement with previously reported values for brush border membranes (18). Theoretically, the decreased $\mathrm{Ca}^{2+}$ uptake activity in the brush border fractions might also relate to a difference in the orientation of the $\mathrm{Ca}^{2+}$ pump, which would depend on the "sidedness" of the vesicles in each preparation. The orientation of these placental vesicles has not been clarified at present. Furthermore, the rate of efflux from the brush border preparations might be more rapid than in the microsomal fraction, although oxalate was present during these studies to minimize this possibility. Mitochondrial concentration to the $\mathrm{Ca}^{2+}$ uptake is unlikely because neither azide nor oligomycin inhibited $\mathrm{Ca}^{2+}$ uptake in either membrane fraction. Finally, it is possible that the observed differences in uptake rates were related to intrinsic properties of the components of the membrane or the intrinsic pump activity which is higher in the microsomal fraction. We therefore speculate that $\mathrm{Ca}^{2+}$ uptake activity results from transport vesicles or membranous organelles present within the placental cytosol or from plasma membrane $\mathrm{Ca}^{2+}$ pumps at the trophoblastic basement membrane where $\mathrm{Ca}^{2+}$ would be pumped to the fetal circulation.

Membranous and vesicular structures containing $\mathrm{Ca}^{2+}$ or other cations have been demonstrated within the cytosol of the human placenta by histochemical techniques $(4,16)$, and a role of such structures in $\mathrm{Ca}^{2+}$ transport has been previously suggested. Numerous vesicles and marked endocytotic activity are noted in the apical region (brush border side) of the syncytiotrophoblast (syncytium). Apical plasma membrane, possibly containing bound $\mathrm{Ca}^{2+}$, is internalized in the intermicrovillous region of the brush border possibly related to an interaction of the plasma membrane with "coated vesicles." The plasma membrane associated with vesicles can be identified even as the vesicle moves through the syncytium towards the fetus and cations have been identified within these vesicles by histochemical techniques (16). Whether the vesicles sequester $\mathrm{Ca}^{2+}$ by an ATP-dependent process and/or are related to the $\mathrm{Ca}^{2+}$ uptake process noted in the present study remains to be clarified.

\section{LACK OF RELATIONSHIP TO $\mathrm{Ca}^{2+}$ ATPase}

ATP-dependent $\mathrm{Ca}^{2+}$ uptake has been related to $\mathrm{Ca}^{2+}$-stimulated, $\mathrm{MG}^{2+}$-dependent ATPase in several tissues $(12,19)$. A relationship of $\mathrm{Ca}^{2+}$ uptake to $\mathrm{Ca}^{2+}$-ATPase activity could not be demonstrated in placental fractions. In sarcoplasmic reticulum and the erythrocyte, $\mathrm{Ca}^{2+}$ transport is closely coupled to $\mathrm{Ca}^{2+}$. stimulated ATPase activity $(12,19)$. No $\mathrm{Ca}^{2+}$-stimulated, $\mathrm{Mg}^{2+}$. dependent ATPase could be demonstrated in the present study of placental vesicles, but it is possible that the high activity of nonspecific $\mathrm{Mg}^{2+}$-ATPase, $\mathrm{Ca}^{2+}$-ATPase, and alkaline phosphatase obscures a possible $\mathrm{Ca}^{2+}$ transport-related ATPase. In fact, if $\mathrm{Ca}^{2+}$ uptake were tightly coupled to ATPase activity, the low activity of $\mathrm{Ca}^{2+}$-stimulated ATPase activity which relates to $\mathrm{Ca}^{2+}$ transport would not be easily demonstrated by the usual chemical techniques because of the high nonspecific $\mathrm{Mg}^{2+}$-ATPase activity present in placental fractions. The characteristics of $\mathrm{Ca}^{2+}$-stimulated ATPase (present mainly in brush border membrane) were distinct from the $\mathrm{Ca}^{2+}$ uptake process which was present mainly in microsomal membrane. Furthermore, if $\mathrm{Ca}^{2+}$ uptake resulted from this high $\mathrm{K}_{\mathrm{m}}$, non- $\mathrm{Mg}^{2+}$-dependent ATPase, the coupling ratio of ATP hydrolysis to $\mathrm{Ca}^{2+}$ transport activity in these placental membrane fractions would be extremely high. Finally, because the $\mathrm{K}_{\mathrm{m}}\left(\mathrm{Ca}^{2+}\right), \mathrm{pH}$ maximum, and the effects of inhibitors are discrepant for $\mathrm{Ca}^{2+}$ uptake and $\mathrm{Ca}^{2+}$-ATPase activity, we suggest that $\mathrm{Ca}^{2+}$-ATPase is not directly related to $\mathrm{Ca}^{2+}$ transport in placental vesicles.

\section{CONCLUSION}

The ATP-dependent $\mathrm{Ca}^{2+}$ sequestration activity presently described in microsomal and brush border human placental membrane fractions is likely to be a mechanism for regulation of intracellular $\mathrm{Ca}^{2+}$. Regulation of intracellelar $\mathrm{Ca}^{2+}$ can be achieved either by pumping $\mathrm{Ca}^{2+}$ into vesicular or membranebound structures within the placental cytosol or by actively pumping $\mathrm{Ca}^{2+}$ from the cytosol to the fetus at the expense of ATP hydrolysis at the trophoblastic basement membrane. $\mathrm{Ca}^{2+}$ binding to placental membranes and uptake into placental membrane vesicles may also represent a step in the "active" $\mathrm{Ca}^{2+}$ transport process which occurs across the human placenta.

\section{REFERENCES AND NOTES}

1. Bruns, M. E., Fausto, A., and Avioli, L. V.: Placental calcium binding protein in rats. J. Biol. Chem., 253: 3186 (1978).

2. Chance. B.: The energy-linked reaction of calcium with mitochondria. J. Biol. Chem., 240: 2729 (1965).

3. Clyman, R. I., Manganiello. V. C., Lovell-Smith, C. J., and Vaughan, M. Calcium uptake by subcellular fractions of human umbilical artery. Am. J. Physiol., 231: 1074 (1976).

4. Croley, T. E.: The intracellular localization of calcium within the mature human placental barrier. Am. J. Obstet. Gynecol., 117: 926 (1973).

5. Delivoria-Papandopoulos, M., Battaglia, F. C., Bruns, P. D., and Meschia, G. Total, protein-bound. and ultrafilterable calcium in maternal and fetal plasmas. Am. J. Physiol., 213: 363 (1967) 6. Fiske, C. H., and Subbarow, Y.: The colorimetric determination of phosphorus.
J. Biol. Chem., 66: 375 (1925).

7. Hudson. D. A.: Uptake of calcium by microvillous membrane of intestinal epthelial cells. Life Sci., 16: 117 (1975).

8. Katz, A. M., Rapke, D. I., Upshaw. J. E., and Polascik, M. A.: Characterization of dog cardiac microsomes. Biochim. Biophys. Acta, 205: 473 (1970).

9. Kletzien, R. F.. Pariza, M. W.. Becker, J. E., and Potter, V. R.: A method using
3-O-methyl-D-glucose and phloretin for the determination of 3- $O$-methyl-D-glucose and phloretin for the determination of intracellular
water space of cells in monolayer culture. Anal. Biochem., 60 : 537 (1975).

10. Leslie, S. W., and Borowitz, J. L.: Evidence for a plasma membrane calcium pump in bovine adrenal medulla but not adrenal cortex. Biochim. Biophys. Acta.. 394: 227 (1975).

11. Lowry, O. H., Rosebrough, N. J., Farr, A. L., and Randall, R. J.: Protein measurement with the Folin phenol reagent. J. Biol. Chem., 193: 265 (1951).

12. Martonosi, A., and Feretos, R.: Sarcoplasmic reticulum. I. The uptake of $\mathrm{Ca}^{2+}$ by sarcoplasmic reticulum fragments. J. Biol. Chem., 230: 648 (1964).

13. Miller, R. K., and Berndt, W. O.: Evidence for $\mathrm{MG}^{++}$-dependent $\mathrm{Na}^{+}+\mathrm{K}^{+}$activated ATPase and $\mathrm{Ca}^{++}$-ATPase in the human placenta. Proc. Soc. Exp. Biol. Med., 143: 118 (1973).

14. Moore, L., Chen, T., Knapp, H., and Landon, E. J.: Energy-dependent calcium sequestration activity in rat liver microsomes. J. Biol. Chem., 250: 4562 (1975).

15. Moore, L., Fitzpatrick, D. F., Chen, T., and Landon, E. J.: Calcium pump activity of the renal plasma membrane and renal microsomes. Biochim. Biophys. Acta.,
345: 405 (1974). 
16. Ockleford C. D. and Whyte, A.: Differentiated regions of human placental cell surface associated with exchange of materials between maternal and fetal blood-coated vesicles. J. Cell Sci.. 25: 293 (1977)

17. Potter. J. D.. and Gergely, J.: The calcium binding and magnesium binding sites of troponin and their role in the regulation of myofibrillar adenosine triphosphatase. J. Biol. Chem., 25: 4628 (1975).

18. Ruczycki, S. M.. Kelly, L. K., and Smith, C. H.: Placental amino acid uptake. IV. Transport by microvillous membrane vesicles. Am. J. Physiol., 234: C27 (1978).

19. Schatzmann, H. J., and Vincenzi, F. F.: Calcium movements across the membrane of human red cells. J. Physiol (Lond.), 201: 369 (1969).

20. Shami, Y.. Messer, H. H., and Copp, D. H.: Calcium uptake by placental plasma membrane vesicles. Biochim. Biophys. Acta, 401: 256 (1975).

21. Shami, Y.. and Radde, 1. C.: Calcium-stimulated ATPase of guinea pig placenta. Biochem. Biophys. Acta., 249: 345 (1971).

22. Smith. C. H., Nelson, D. M., King. B. F., et al.: Characterization of a microvillous membrane preparation from human placental synctyiotrophoblast: a morphologic. biochemical and physiologic study. Am. J. Obstet. Gynecol.. 128: 190 $(1977)$

23. Smith. N. C., and Brush, M. G.: Preparation of human placental villous surface membrane. Nature (Lond.), 252: 302 (1974).

24. Trotta, E. E., and DeMeis, L.: ATP-dependent calcium accumulation in brain microsomes. Enhancement by phosphate and oxalate. Biochim. Biophys. Acta.
394: 239 (1975).

25. Wasserman, R. H., and Taylor, A. N.: Some aspects of the intestinal absorption of calcium, with special reference to vitamin D. In: C. L. Comar, F. Bronner: Mineral Metabolism. Vol. 3, pp. $321-403$ (Academic Press, Inc., New York. 1969).

26. Whitsett J A and Johnson, C.: Differences in the localization of insulin receptors and adenylate cyclase in the human placenta. Am. J. Obstet. Gynecol., 133: 204 (1979).

27. Whitsett. J. A., and Lessard, J. L: Characteristics of the microvillous surface membrane: insulin receptor localization in brush border membranes. Endocrinology, l03: 1458 (1978).

28. Whitsett. $\mathrm{J}$. And Wallick, E. T.: A study of ${ }^{3} \mathrm{H}$-ouabain binding and $\mathrm{Na}^{+}, \mathrm{K}^{+}$ ATPase in the human placenta. Endocrinol. Metab., 238: E38 (1980).

29. Wilkinson, G. N.: Statistical estimations in enzyme kinetics. Biochem. J., 80: 324 (1961).

30. Requests for reprints should be addressed to: Jeffrey A. Whitsett, Department of Pediatrics. University of Cincinnati College of Medicine, 231 Bethesda Avenue. Cincinnati, OH 45267 (USA).

31. This research was supported in part by Children's Hospital Research Foundation. Cincinnati $\mathrm{OH}$, and NIH, NICHD Grant 11725 .

32. Received for publication April 2, 1979.

33. Accepted for publication August 13, 1979. 